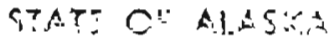

Department of Natural Resources
PROPERTY OF LIBRARY

Division of Mines \& Geology STATE OFM, LASKA

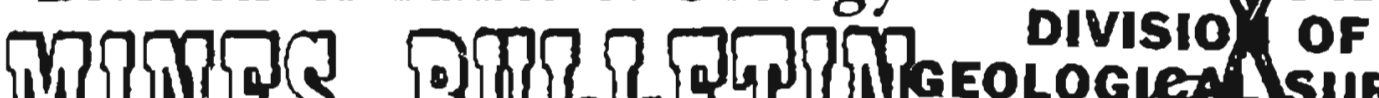
duswe boubligh GEOLOGIFa' SURVEY

\title{
VoI. XVIII
}

MAY 1970

No. 5

P.O. Box 5-300

Collego, Alakk 99701

KENDRICR BAP MINING CO.

CITIES SERVICE MINERAIS CORP.

BURRAU OF MINES, ALASKA POST

KAISER STHEL CORP.

JAPANESE METAL MARRET

\section{IN THIS ISSUE INTERIOR'S BUREAU OF MINES REORGANIZED}

BULLETIN CIRCULATION

MINING CLAIMS

NEW PUBLICATIONS

METAL MARKET

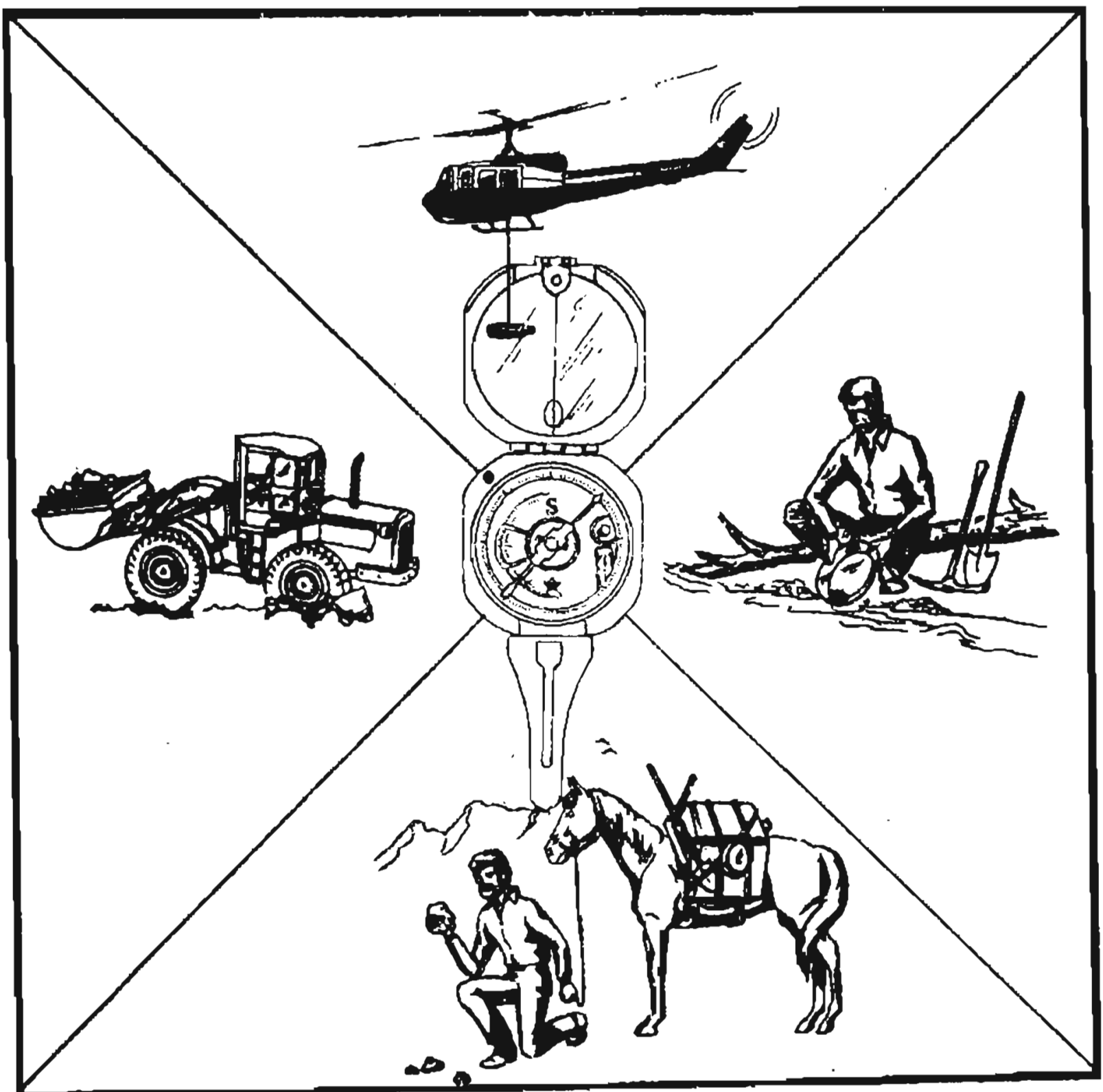

Published to Accelerate the Develapment of the Mining Industry in Alaska Keith H. Miller - Governor 
$\because$

$i=$

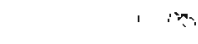

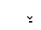

:

$\rightarrow \cdots$

$\therefore$,

$\div$

:

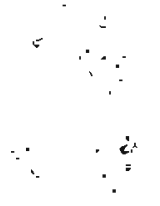

$\cdots$

. 


\section{KRNDRICK BAY MYNING COMPANY}

Core drilling on the Kendrick Bay Mining Co. property" on Prince of Wales Island, Alaska has confined the presence of a moderate tonnage of high grade uranium-thorium ore, accordlng to Standard Hetals Corp., which owns more than 80 pexcent of Rendrick Bay. The core drillIng was carried out by Newnont Exploration Ltd, a subsldiary of Newmont Mining Corp., under a jolnt agreement entered into early last year with Kendrick Bay. The tonnage discovered is not large enough to justify coutsuction of a treatment plante on the Kendrick Bay property but enough uranium-thorju ore has been found to make it practical to shtp and mill the ore at anothet: Newront subsidiary, Dawn Mining Co." In Ford. Washington. Prepaiations for the development of the mine and subsequent mining of uratitim will probably begin as soon as weathex: conditions permit:

P

Citles Service Ainerals Corp., a subsidiary of Cityes Service Company wili resume work this May in the copper exploration tenture ic t's nianaging neir Denali, Alaska. Diamond drilling is planned along a 1400 foot decline to test the deposit at greater depth. Approximately 20 men will be employed at the site with the possibility of an expansion in the work force if results continue to be favorable:

\section{BUREAU OF MINES: ALASKA POST}

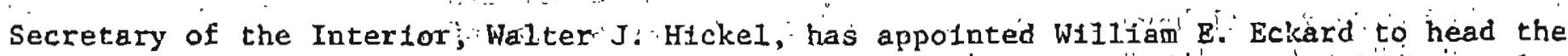
Interior Department's Bureau of Mines in Alaska: Eckard, a native' Pittsburgh, Pennsylvanian has 20 years federal regearch experfence in petroleum development and production engineering. He will be chief of the Bureau's Alaska office of Mineral Resources, with headquarters in. Juneau.

In cgpmenting on Eckard's"appolntment, secretary Hickèl'sald, "The vast mineral potentlal of Alaska must be realized for the benefit of all Amerlcans; but it must'be reailzed in ways that are wholly compatible with the preservation of environmental quality in the state. The role of the Department's Bureau of Mines will be critical in maintaining the right kind of balance in Alaskan development.". Secretaicy. H1ckel considers the "Junean post a "cructal assignment", vitaj both to the future of Alaska's mineral and fuel development and to the protection of the, 49 ht state's, other natural resources.

\section{KAISER STEEL CORP.}

Reports have been recelyed thatrkalser Steel Corp. Is planning an extensive coal prospectíng program next sumer in the Cape Beaufort area on the northwestern flank of the Brooks Range. The primary area of interest is the Kukpowruli River Valley where AMOR has done fielo examinations over the past few years.

Baged on limited laboratory, tests, the Cape Beaufbrt coals appear to' have'fair to good coking characteristics when blended. A rajor problem of the area ls trantsportaton. One plan under consideration is an offshore deep-water loading platform with a slurry pipeline from shore.

\section{JAPANESE METAL MARKET}

Unofficlal word has been received that Japan is not as interested in copper os she was year or so ago because of the apility to secure sources of supply all over the world, expectaliy... in Africa and South America. The Japanese are now turning thejr attention to zinc, which. they need plenty of. They are Interested in contacting property holders who'have substan-" tial reserves. The inc production from the new Anvil Mine in the Yukon 'is' be'ing purchased by a Japanese firm. 


\section{INTERIOR'S BUREAU OF MINES REORGANIZED}

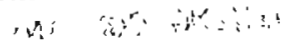

Reorganization of the Interior Department's Bureau of iflnes--deqlgned to strengthen and factlttate both its law enforcement activities and its mineral fesearch and development "functions-has been announced by Secretary Wrater. H. Hickel.

The reorganization, first to enconpass the entire Bureau of ilnes since 1963; is belng put into effect Immediately, Secretaryi Hjckel said. Among its major objectives are:

-Assurance that the Bureau's responsiblitties for administexing itough thew mine health and safety laws will be carried out;

-

- dental problems move rapidly forward to make the Bureau more responstve to currant needs on the environmenta]. front. Two new units, kave been created especlally to deal with pollution and waste problems;

--Closer and nore productive relationships with State and localigovernments;

- Improved efficiepay and ecoriomy-in the collection and dissemination of economic

'ád statistical. information on mineral development;

$\therefore$ : Greater emphasis op afneral and energy supply problems and 1mprovements of

- the Bureau's abildty to detect, deffine, and help solve them.

Secretary Hickel sald that a key feature of the reorganlzation is the establishment of two Deputy Director positions, Immediacely beneath the Bureau's Director 1n management responsiblity. One Deputy will have direct charge of the Bureau's law enforcement activities in mine health and safety; the iquber will adrinister all Bureau. research and environimtal development functions.

$3, \therefore$

Other aspects of the reorganization, the Secretary said, are aimed at achieving greater emphasig on envitonmental problemg associated with the mining and processing of minerals and., fuels; at better coordination of fact-finding functlons. wh research and development activIties; and at more effective concentration of the Bureau's fleld staff.

Commenting fürthex on the reorganization, Secretary Hickel sald it stemed frón a recognttion of three relatively recent developments on the national scene: (1) the growing concern over waste and pollution and the need to actack them constructively through research; (2) new legislation that has given Intertor greater enforcement powers in the fleld of mine health and safety; and, (3) Increasing varlety and complexity in mineral and energy supply problems, all of which demand greater Federal involvement.

"The reorganization is expressly deslgned to strengthen the Bureat's capabilitieg in. responding to each of theșe major developments," Secretary Hickel sald.

$$
\text { BUELETIN CIRCULATION }
$$

We thought our readers might be interested in where the Mines Bulletin "1s sent. The followIng laformation pertains : to last month's issue.

A total of 2178 'Bulletins were malled, 1075 to Alaska, 918 to other States, 172 to Canada, and 13 to other countries.

At least 100 Bulletins go to unfversity or public libraries; 200 to federal goverament agen-11.: cies; and 150 to state and city governments. We estimate that at least jड़่o Bulletins are mailed to mining and exploration coipanies or cofperations. - Wany of the larger companies recelve Bulletins at most of their major offices thoughout the United States and Canada. Approximately 978 Bulleting reach individua people lnterested in Alaska. A breakdown by ctty and area followa: 


\section{'ilaska}

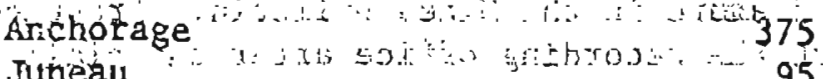
Junea

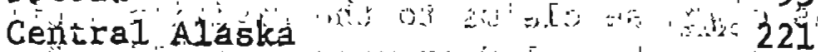

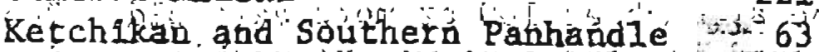

Falrbanks

Interlor, and Westera Alaska, $\quad 121$

vórthern Panháaile A :

$$
\text { so }
$$

States

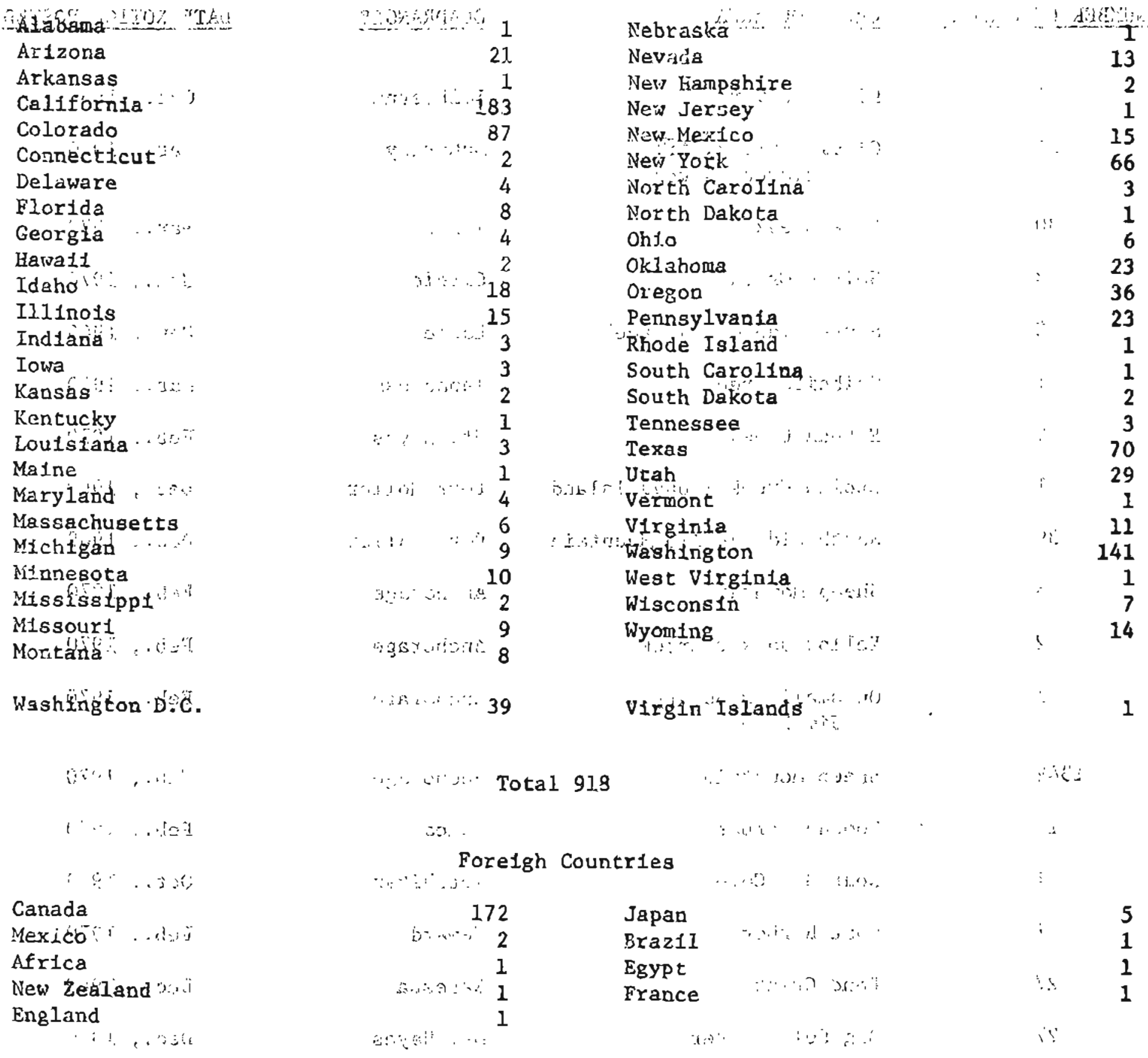

Total 185 
We will try to make the following chart wonthly feature in the Mines Bulletin. Prospectors have up to 90 days to flle a mining claim with the recording office after the claim is staked. The récording offices then forward records of these claims to the Division's. office at College. Thus the material in this chart may be as much as 100 or more days "old. "Recent claim notices have falled to Ilst the commodity staked for and thus we are unable to ilst this information as part of the chart. It is hoped that in the future prospectors will $118 \mathrm{~s}$ the mineral or metal staked and thus enable a more complete filing of information on the State's minerals in the Division records.

\section{NIMBER OF CLAIMS}

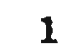

30
CREEX OR AREA

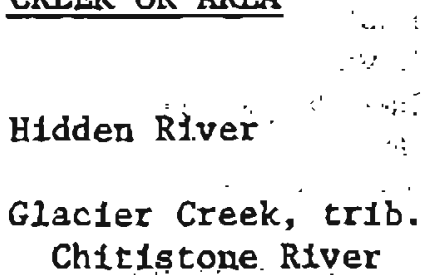

Buck Creek

Sw1tch Creek

South stde of By' Creek

Stibnité Creek

Eureka Creek

Apollo Creek - Unga Island

South side Apollo Mountain

Sheep Mountein

Yellow Jacket Creek

On smalf tributary to Jim Lake
QUADRANGLE

Talkeetna

McCarthy

Teller

Circle

Eagle

Tanacross

Mt. Hayes

Port Moller

Port Moller

Anchorage

Anchorage

Anchorage

Anchorage

Juneau

Retchikan

$\therefore$

Seward

Nabesna

Mt. Hayes
DATE NOTICE POSTED

Oct., 1969

Max., 1970

Mar ., 1970

Jan., 1970

Nov., $1969^{\circ}$

Mar., 1970

Feb., $1970^{\circ}$

Dec., 1969

Dec.: 1969

Feb, 1970

Feb., 1970

Feb., 1970

Feb., 1970

Feb., 1970

Oct., 1969

Feb., 1970;

Dec . 1969

Dec., 1969

$$
\begin{aligned}
& -x \leq \quad 5030 \\
& -4-
\end{aligned}
$$




\section{NEW PUBLICATIONS}

The following open flle reports have been released by the U.S. Geological Survey and are avallable for consultation in the Alaska U.S.G.S. and State Division of Mines and Geology offices. Material from which coples of these open file reports can be made at private

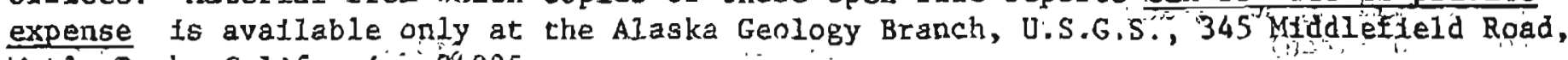
Menlo Park, California 94025.

Hetallic mineral resources maps of seven Alaska quadrangles: Chignlk, Cold
Bay, Dilingham; Lake Clatk, Naknek, Port Moller, Unalaska, by Edward H. Cobb.
6 p., 7 maps, 1 Index map, 1 explanerion, (total, 24 sheets). Scale 1:500,000.

Bering Sea, selismic reflection profiles, 1969 , by David W. Scholl and Michael S. Marlow. 1 navigation chart; 17 sejsmic profiles.

Analysis of Shublik Formation rocks from Mt. Michelsnn quadrangle, Alaska," by Robert L. Detterman: 4 sheets (I cover sheet, I strat. section, I graph, 1 table).

\section{Preliminary Report Release}

On Monday, May 11, 1970, the Divtsion of Mines and Geology will release a brief summary of the results of a geologtcal and geochenlcal investigation. This preliminary report will be available over the counter at the Division office in College (University and College Avenues) and Archorage (3001 Porcuplne Drive) at 9:00 A.M., ADT and at the Juneau office (Goldsteln Bullding) at 11:00 A.M., PDT. The report is, free of charge, and w11l be avallable by ma1l from the Division offlice, Box 5-300, College, Alaska 99701. All mall requests recelved prior to May 11, 1970 will be malled from College on that day.

'i.
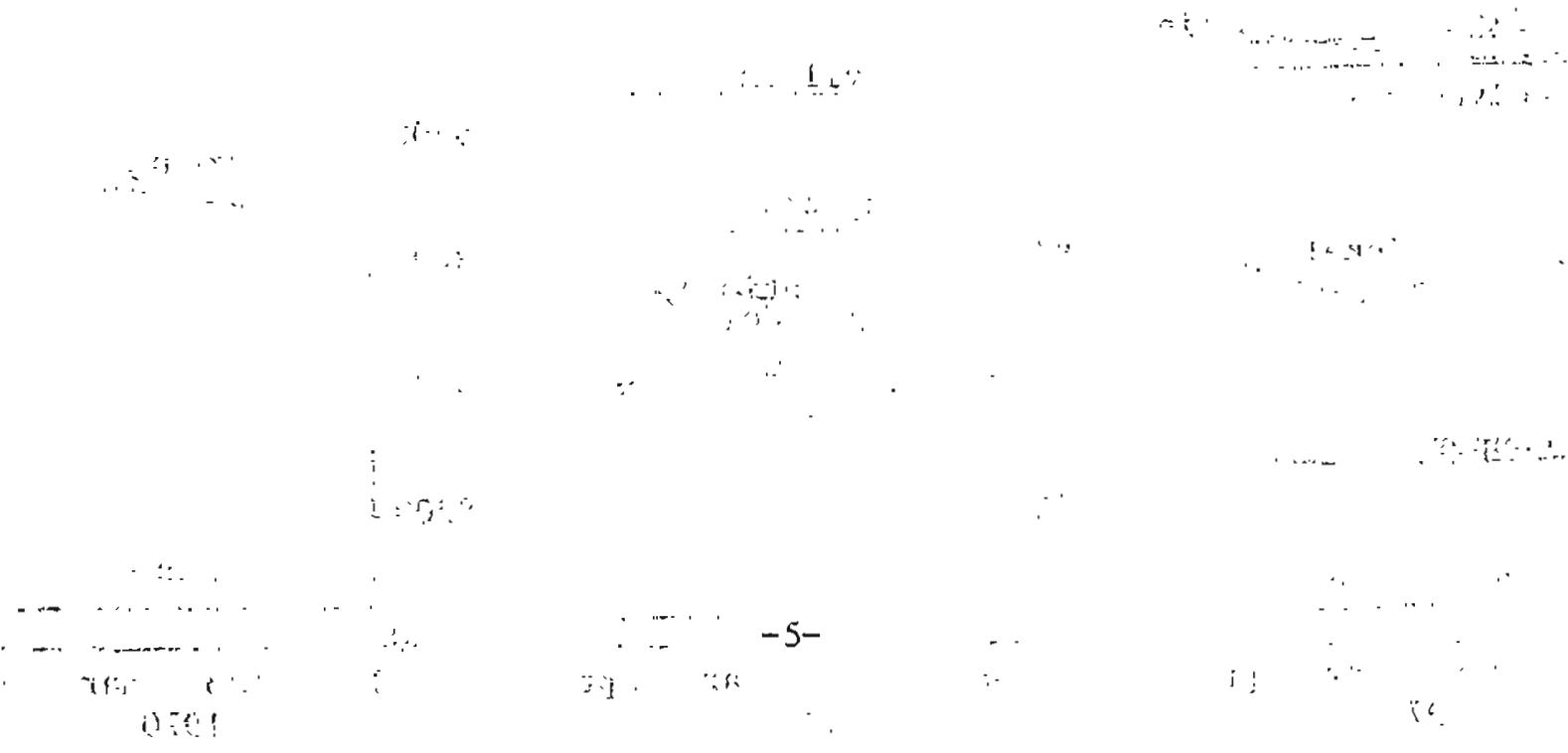
Antimony ore, stu equivalent. European ore

$\$ 38.39-40.17$ $\$ 38.39-40.17 \ldots 9.54-7.72$

Barite far1liting mud grade from E/MJ'Harch)

$\$ 12-16$

$\$ 12-16$

$\$ 12-16$

Chrome ore long ton

$\$ 31-35$

$\$ 31-35$

$\$ 31-35$

Copper per 1b.: 1

59. $7 \mathrm{~F}$

Gold per oz: "all

$\$ 36.65$

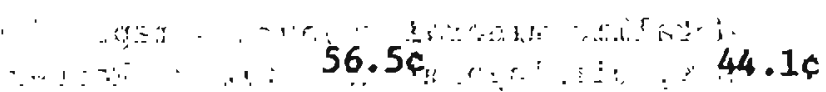

Lead per 1b.

16.54

$\$ 35.43$

$\$ 43.45$

Mercury per Elask

$\$ 467-473$

$\therefore, 16,5 c$

14.36

Molybdenum conc per lb.

$\$ 1.72$

$\$ 470=480$

$\$ 497-510$

Nickel per lb.

\$1. 28

Platinum per oz.

$\$ 130-135$

$\$ 1.72$

$\$ 1.62$

Silver, New York, per oz.

$185: 94$

$\$ 1.00$

$\$ 1.03$

$\$ 130-135$

$\$ 120-125$

Tin'per 'ib.

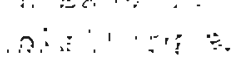

187.04

T1tantum ore per ton

$\$ 30-35$

$186.8 c$

$175.6 c$

Tutgsten per unit

$\$ 43.00$

$16.0 \mathrm{c}$

Zinc per $1 b$.

$\$ 54-66$

$178.3 \mathrm{C}$

1.57 .36

$\therefore$ \$30-35 $\because: \because 2=\$ 20-21$

$1010-21$

Beryllium powder 98\%

$\$ 43,00$

$\$ 43.00$

16.04

14.04

$\$ 54-66$

$\$ 54-66$
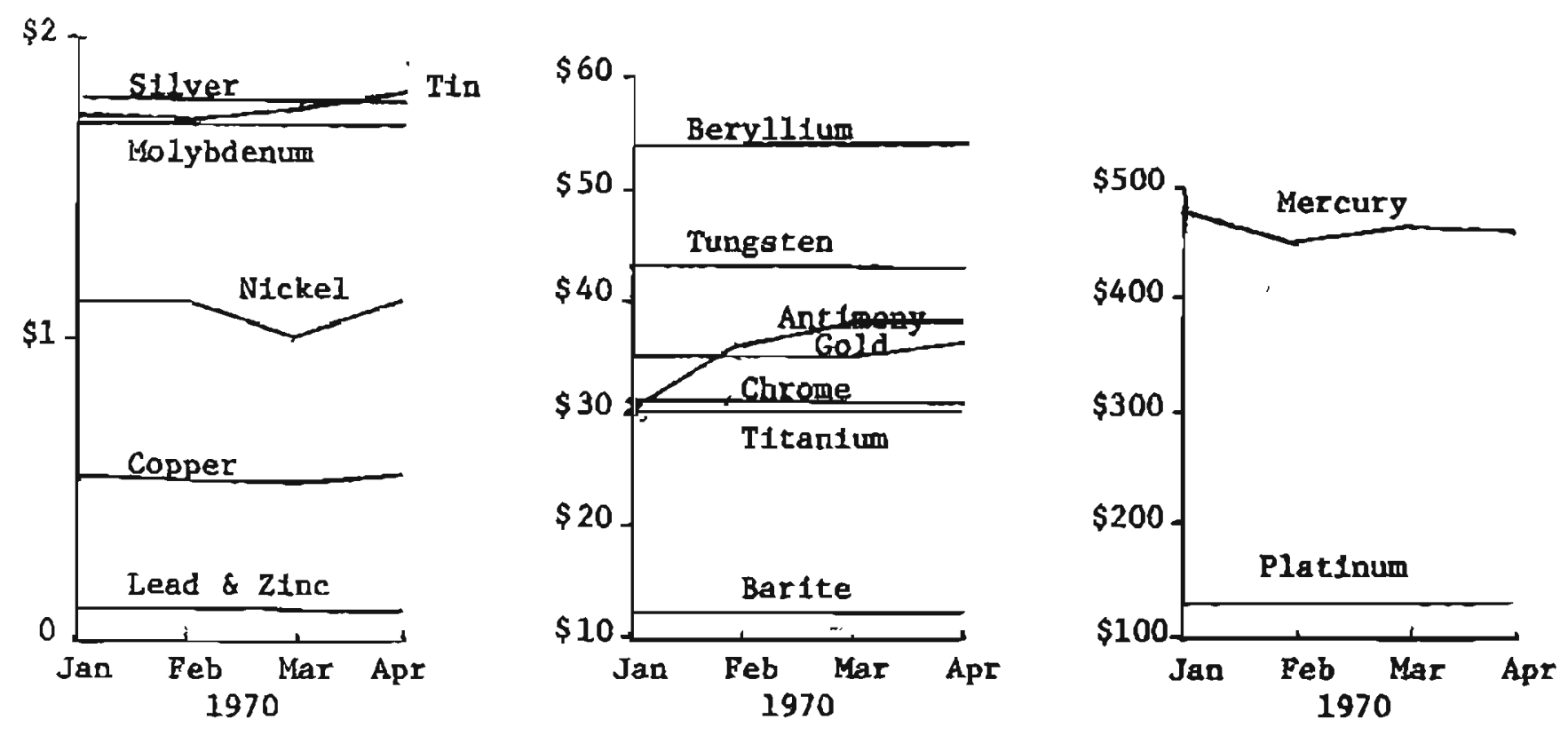

$-6-$ 